\title{
People and urban nature: the environmentalization of social movements in Bogotá
}

\author{
Germán A. Quimbayo Ruiz ${ }^{1}$ \\ University of Eastern Finland, Finland
}

\begin{abstract}
Using research conducted in Bogotá, Colombia, I discuss in this article how urban nature has been used as a vehicle by social movements to contest urban commons. The article explores the "environmentalization" of strategies and repertoires of social movements in urban struggles dating back to the 1980s, which developed in parallel with public urban planning debates. In recent years these were nurtured in turn by environmental discourse in a quest to change the city's growth paradigm. I suggest that the legitimacy of knowledge and law about urban nature advocacy is co-created by communities confronting institutions that are supposed to represent state power. This case study analyses conceptualizations of urban nature in and from Latin America, and shows that urban politics and environmental issues are part of a process in which political mobilization is a key element to overcome socio-ecological inequalities.
\end{abstract}

Key words: urban social movements; political ecology of urbanization; situated knowledge; socio-ecological inequalities; Latin America

\section{Résumé}

Dans cet article, je discute de la manière dont la nature urbaine a été utilisée par les mouvements sociaux pour contester les biens communs urbains. À l'aide de recherches menées à Bogotá, en Colombie, l'article explore "l'environnementalisation" des stratégies et répertoires des mouvements sociaux dans les luttes urbaines des années 1980, qui s'est développée parallèlement aux débats publics sur l'urbanisme. Au cours des dernières années, le discours sur l'environnement s'est inspiré de ces discours pour tenter de changer le paradigme de la croissance de la ville. Je suggère que la légitimité du savoir et du droit en matière de défense de la nature urbaine soit co-créée par les communautés confrontées aux institutions censées représenter le pouvoir de l'État. Cette étude de cas analyse les conceptualisations de la nature urbaine en Amérique latine et à partir de celles-ci. Il montre que la politique urbaine et les problèmes environnementaux font partie d'un processus dans lequel la mobilisation politique est un élément clé pour surmonter les inégalités socio-écologiques.

Mots clés: mouvements sociaux urbains; écologie politique de l'urbanisation; connaissances localisées; inégalités socio-écologiques; Amérique latine

\footnotetext{
${ }^{1}$ Germán A. Quimbayo Ruiz, MSc. PhD student and researcher at the Department of Geographical and Historical Studies, University of Eastern Finland, Joensuu, Finland. EmailS: german.quimbayo "at" uef.fi; gquimbayo "at" gmail.com. The research in this article was supported by the 'Rodolfo Llinás funding program for Promotion and Advance of Scientific Spirit in Bogotá' of the Fundación Centro de Estudios Interdisciplinarios Básicos y Aplicados (CEIBA) in Bogotá, Colombia. Thanks also to the Center for Research and Popular Education in Colombia (CINEP), in Bogotá, for the use of their databases. Many ideas from this article were a product of presentations in both Colombia and Finland. My acknowledgements for encouraging, patient, and wise support go to: Professor Juha Kotilainen at the Department of Geographical and Historical Studies, University of Eastern Finland (UEF), Joensuu, and Dr. Matti Salo at Natural Resources Institute Finland (Luke) in Turku. Likewise, I would like to thank two anonymous JPE reviewers for their useful comments. Special thanks for comments on previous versions go to Dr. Diana Ojeda at Instituto Pensar, Pontificia Universidad Javeriana, Bogotá, and Oscar Pedraza at The Graduate Center of The City University of New York, USA (CUNY). Thanks to Juha Halme and Karli Storm at UEF, and Fernando Castillo, for valuable comments at early stages (2017). Last, but not least, I extend my acknowledgements to all the courageous people on the ground in Bogotá (activists, practitioners, companions, friends, you know who you are!) who shared their views and feelings and helped me to imagine a more just city-region.
} 


\section{Resumen}

A través de una investigación llevada a cabo en Bogotá, Colombia, en este artículo argumento cómo la naturaleza urbana ha sido usada como un vehículo por movimientos sociales en la lucha por los comunes urbanos. El artículo explora la ambientalización de estrategias y repertorios de los movimientos sociales en luchas urbanas que se remontan hacia la década de 1980, en paralelo con debates públicos de planeación urbana. Aquellos debates, a su vez, fueron enriquecidos en años recientes con el discurso ambiental como una apuesta para cambiar el paradigma del modelo de crecimiento de ciudad. En el artículo también sugiero cómo la legitimidad del conocimiento y la ley sobre la defensa de la naturaleza urbana es co-creada por las comunidades que confrontan las instituciones que se supone representan el poder estatal. Este estudio de caso es una contribución para traer juntas conceptualizaciones acerca de la naturaleza urbana en y desde América Latina. Asimismo, la investigación ofrece algunas lecciones sobre cómo la política urbana y las preocupaciones ambientales son parte un mutuo proceso en donde la movilización política es un elemento clave para superar desigualdades socio-ecológicas.

Palabras clave: movimientos sociales urbanos; ecología política de la urbanización; conocimiento situado; desigualdades socio-ecológicas; América Latina

\section{Introduction}

Recent conceptualizations of social movements and environmental struggles in Latin America have fallen within the "commodities consensus" debate (Svampa 2012). Social movements in Latin America have been receiving attention because of the rise of environmental struggles against a set of state-led growth-oriented development paths embodied in extraction and exploitation activities such as mining, hydrocarbon exploration, land grabbing for food, and other energy industries (Burchardt and Dietz 2014; Gudynas 2009; Martínez Alier et al. 2014; Martínez Alier et al. 2015; Pérez-Rincón et al. 2018). However, in this debate such movements and their eco-political actions are often portrayed romantically. There is a lack of analysis in this debate about how situated knowledge intertwines with normative and technical-scientific concepts in everyday environmental struggles, particularly in urban settings. Moreover, the role of social movements in socio-ecological processes, including urbanization, is just beginning to be explored by researchers in Latin America (Quimbayo Ruiz and Vásquez Rodríguez 2016; see also Arboleda 2016a; Parra and Gitahy 2017).

This article seeks to identify the specific role of social movements in advocating for urban nature in Bogotá, the capital of Colombia. I argue that ideas of urban nature embodied in hills, wetlands, rivers, and streams in Bogotá have been used as a vehicle by social movements to reclaim the urban commons. This article thus explores the environmentalization of strategies and repertoires of such movements in urban struggles dating back to the 1980s, in parallel with urban planning initiatives. Since the late 1980s a set of social organizations in Bogotá have been promoting urban nature advocacy, emerging as a local environmental movement (movimiento ambiental). This social movement comprises grassroots organizations, scholars, and practitioners, who formerly advocated for better urban services, but later strengthened their interests throughout urban nature advocacy. Moreover, they have been building a territorial attachment with some elements of urban nature through the re-appropriation of the scientific-political concept of 'Main Ecological Structure' (Estructura Ecológica Principal) (henceforth, MES) (van der Hammen 1998) which was developed as a structural framework for environmental planning in the Bogotá region. "Environmental territories" (territorios ambientales $)^{2}$ are socio-political constructions that reflect multiple appropriations of urban nature in the everyday life of people and their neighborhoods (Julio and Hernández 2014).

While the urbanization process in the Bogotá region has been conditioned in many ways by the sociopolitical order of a country struggling to put an end to a long armed conflict, I shall not discuss these matters directly. Rather, the article attempts to understand how environmental mobilization is framed in such a setting. Therefore, Bogotá as a whole, throughout this article, is presented as a case study with multiple environmental

\footnotetext{
${ }^{2}$ Here the concept of territory, in Spanish territorio, is akin to the one discussed by by Echeverría and Rincón (2000); Santos (2000); Haesbaert (2013), and Schwarz and Streule (2016).
} 
conflicts related with urban nature at the metropolitan scale. The time frame of my research is from the late 1980s to the present. Although each individual conflict identified within this time frame is not scrutinized in depth, their most relevant features are highlighted with the aim of understanding how the environmentalization of social mobilization has taken place through advocacy of urban nature.

The article is structured as follows. First, I introduce my key concepts related to social movements and their engagement with environmental issues, highlighting the relevance of these matters for urban Latin America. Along with this, I describe the case study, methods, sources of materials and the methods of the research. In the empirical section, I explore the role the role of social organizations in Bogotá, and the environmentalization of their actions in struggles for urban commons. I also describe how environmental advocacy became institutionalized, highlighting notable contradictions in everyday practices of people and social organizations. In the final section the main points of the article are summarized as concluding remarks.

\section{Framing the environmentalization of urban social movements}

Social movements and their engagement with environmental issues are reflected in myriad organizations embracing countless struggles and interests (Armiero and Sedrez 2014; O'Neill 2012). Such issues are not exempt from socio-economic inequalities and material shortcomings related to class, gender, race, or identity (Wolford and Keene 2015). Indeed, most environmental concepts have origins outside the scholarly world, at the grassroots in, for instance, the Environmental Justice Movement (Martínez Alier et al. 2014; Temper et al. 2015). Therefore, environmental struggles are necessarily involved in advocating for the right to live in other ways different of those established by the contemporary neoliberal economy, and, at the same time, in promoting alternatives for sustainability transitions (c.f. Scheidel et al. 2018).

The action of environmental movements in urban settings has been most commonly referred to in the context of conflicts concerning the management and disposal of hazardous waste, particularly in poor or racialized neighborhoods (Auyero and Swistun 2009; Di Chiro 2008). Nevertheless, there has recently been an increasing amount of conflict related to urbanization, and how the urban space is used in land speculation, mainly for real estate developments, affecting ecosystems such as wetlands (Pintos 2017). Land speculation can also transform landscape values which embody means of life, for instance, for farming communities living at the metropolitan urban-rural fringes (Gómez et al. 2016). Although the articulation of values around urban nature (Ernstson and Sörlin 2013; Erixon Aalto and Ernstson 2017) and social production of urban ecosystem services (Ernstson 2013) have been studied, less attention has been paid to how peoples' daily actions produce diverse social movements in urban nature advocacy. The exercise of advocacy means how people can take action on behalf of nature, and how such action can become a legitimate vehicle in broader struggles for urban commons.

In addition, the causes and drivers of environmental conflicts are many. In such conflicts, materiality cannot be separated from its symbolic meanings in everyday practices (c.f. Shillington 2011) of environmental mobilization, and political and ideological drivers, environmental movements' repertories of action and the resulting outcomes come together to shape and produce a place (c.f. Ulloa 2015). To enable the politics of place it is important to take into account how places are produced, and, moreover, how global concerns are also being produced at the local scale (c.f. Massey 1992). Repertoires of action of such movements are therefore not only local, because they are actually related to multi-scalar struggles.

On the other hand, urban commons are also environmental commons (Harvey 2012), and they are constantly shaped and negotiated by situated knowledge and daily actions of social movements in specific places, that take part in struggles to overcome socio-ecological inequalities (Lawhon et al. 2014; Loftus 2012). Such inequalities can be understood, following the contribution made by Schlosberg (2007), as having three dimensions:

(1) distribution: associated with access to environmental goods and services, and economic and social benefits related to their use, enjoyment and exploitation, and, likewise, to whom the 
impacts or negative effects of use or exploitation fall (i.e. processes of pollution, contamination, or environmental harm);

(2) participation: corresponding to the injustices that are produced in decision-making and legal procedures associated with the use or management of environmental or natural property and services;

(3) recognition: to achieve equality, it is important to recognize others, their culture, rights, cosmologies, ontologies, amongst others.

In this sense it is important to explain an environmentalization of everyday politics of urban commons in order to understand broader political mobilizations for overcoming socio-ecological inequalities (c.f. Agrawal 2005; Buttel 1992).

Therefore, debates around social movements and urban nature can contribute to increasing interest in recent uprisings elsewhere that are related to urbanization (Dikeç and Swyngedouw 2017; Erensü and Karaman 2017; Merrifield 2013). Environmental issues have also been co-opted by transnational capitalism whose sustainability agenda, including urbanization, is biased toward market-based approaches (Allen et al. 2016). Imperatives such as "green cities" (c.f. Haase et al. 2017) or addressing climate change (Di Chiro 2016) have become totalizing narratives forced into the daily life of people, undermining instead of improving their conditions, or even neutralizing their political capability to make social change as subjects or communities (Davidson and Iveson 2015). From a Latin American perspective, while urban politics in the region have long related to demands for social justice, it is also important to document how such demands are articulated through environmental imperatives (see Zeiderman 2016a, for risks and climate change). Recently, there have been important contributions that address issues such as the use of urban space (Fernández Álvarez 2012), allocation of toxic materials in poor areas (Auyero and Swistun 2009), water (Delgado 2015), or unequal flows of energy and materials in urban environments (Arboleda 2016a, b).

It is important to go further in the theorization of Latin American social movements campaigning for urban nature, taking into account the socio-ecological features of urbanization embedded in this 'megadiverse' region (Pauchard and Barbosa 2013) characterized by extreme inequalities (Oxfam 2016). These particular Latin American political ecologies of urbanization (see also Sedrez 2013) present potential challenges in conceptualizing how knowledge about nature is generated in peoples' daily lives through political mobilization (Quimbayo Ruiz and Vásquez Rodríguez 2016). Moreover, there is a need to understand how situated knowledge intertwines with normative and technical-scientific concepts at the everyday level of environmental struggles (c.f. Li 2015).

Situated knowledge, sometimes also referred as "local environmental knowledge", is not fixed. Instead, it is part of wider networks, both influenced by, and influencing, broader political, economic, and social forces such as globalization of markets, technologies, and so forth (Horowitz 2015). Moreover contradictions, paradoxes, or power relations can also be found amongst environmental movements, which can suffer inequalities of class and gender. Indeed, these everyday circumstances challenge problematic depictions of romantic eco-political action in scholarly research on environmental movements. Instead, acknowledging such circumstances, and understanding how situated knowledge is articulated through environmental action, can lead to useful reflections on how best to face sharp socio-ecological transformations and urbanization processes. This article attempts this by focusing on one of many environmental issues: urban nature as an urban commons, and how this issue has been articulated through social justice politics and urban planning in the recent history of the city. 


\section{Situating Bogotá and its urban nature}

Bogotá, the capital of Colombia, is an autonomous municipality known as the Capital District (Distrito Capital) composed of 20 local political-administrative units or localidades. ${ }^{3}$ In 2015, the population of Bogotá was over 7,980,000 (16.6\% of the national total) (DANE cited in DNP 2015) ${ }^{4}$, and the total surface area of the District is $1,635 \mathrm{~km}^{2}$, of which $250 \mathrm{~km}^{2}$ are urban, $29 \mathrm{~km}^{2}$ for planned urban expansion, and $1,227 \mathrm{~km}^{2}$ rural (Alcaldía Mayor de Bogotá 2004; SDP 2017). Bogotá's contribution to the Colombian Gross Domestic Product (GDP) in 2015 was $26 \%{ }^{5}$, and it has maintained a strong macroeconomic performance mainly based on the service sector of the economy; trade and retail, tourism, banking, entertainment, information technology services and real estate developments (DNP 2015). The District forms part of the Sabana de Bogotá, a high Andean plateau (2,600-3,800 meters above sea level) that has been declared a strategic ecosystem for Colombia (Article 61-Law 99/1993). This ecosystem is embodied in hills, wetlands, rivers, and páramos (high altitude wetlands) all framed under the scientific-political concept of MES (see Figure 1). This concept was originally coined by Dutch-Colombian ecologist Thomas van der Hammen (1998) for the Environmental Action Plan for the Bogotá River's watershed. It has since been used by several Colombian environmental scientists, and it has been included in urban planning policies such as the Master Plan for Land-use in Bogotá (Plan de Ordenamiento Territorial - henceforth: POT), which offers this definition:

(...) The Main Ecological Structure is based on the ecological, geomorphological, and original biological structure existing in the territory. The hills, the alluvial valley from the Bogotá river and the plains are part of this basal structure. The set of reserves, parks and remains of the natural vegetation of streams and rivers are an essential part of the desirable main ecological structure and carrying out ecological restoration is fundamental for its realization. The purpose of the Main Ecological Structure is the conservation and recovery of natural resources such as biodiversity, water, air and, in general, the environment desirable for man (sic), fauna and flora(...). (Alcaldía Mayor de Bogotá 2004. Article 72, Decree number 190)

While this definition could be seen to portray a nature/city dichotomy, it is, rather, a socio-ecological product, in which the Bogotá-region unfolds as a hybrid socio-natural entity (c.f. Swyngedouw 1996; see also Ándrade et al. 2013; Gallini and Castro 2015). Although Bogotá has certainly been improving some of its socioeconomic characteristics and its urban development outcomes compared to the beginning of 1990s, so far urban growth in the city-region has resulted from an overt process of producing uneven geographies with insufficient urban planning, and, foremost, from social exclusion, poverty, and violence. These factors are linked to a national armed conflict, and state intervention that led to forced migration from rural to urban areas (PNUD 2011).

In addition, concentration of urban services, and political and financial power, has resulted in a metropolis that has not promoted sustainable socio-spatial integration at the urban region level (Carrizosa 2014; Thibert and Osorio 2014). This results in a negative urban footprint beyond the city limits (Díaz 2011), which has fuelled conflicts around water shortages and the critical pollution of the Bogotá River, land-use, and energy supplies. In effect, this kind of urbanization has also both depleted pre-existing conditions embodied in the MES, and transformed such conditions through a dynamic and mutual socio-natural constitution (as in Figure

\footnotetext{
${ }^{3}$ These are: Usaquén, Chapinero, Santa Fe, San Cristóbal, Usme, Tunjuelito, Bosa, Kennedy, Fontibón, Engativá, Suba, Barrios Unidos, Teusaquillo, Los Mártires, Antonio Nariño, Puente Aranda, La Candelaria, Rafael Uribe Uribe, Ciudad Bolivar, and Sumapaz. Most of these political-administrative units are completely urban, except Ciudad Bolivar, Usme, Santa Fe, San Cristóbal, and Suba, which have both urban and rural areas. Sumapaz is completely rural.

${ }^{4}$ The metropolitan area of Bogotá is not legally constituted, but its relationship with other municipalities (23) is a sort of de facto metropolitan area. By 2020, it is expected that the total share of population between the District and the metropolitan area will be almost 10 million inhabitants (SDP 2014).

${ }^{5}$ The total for the country was estimated as US\$295.1 billion.
} 
2). Urbanization has caused the loss of unique wetlands areas ${ }^{6}$ as well as rich soils to grow food in, and allowed high-impact activities in marginalized and rural areas like the "Doña Juana" municipal landfill or quarrying (mining) activities in the Tunjuelo river's watershed in south Bogotá. ${ }^{7}$ Similarly, urban development for lowincome housing has usually been located on the periphery of the city or outside the boundaries designated by the municipal administration: on stream banks, wetlands and hilly areas that are vulnerable to disasters such as floods or landslides. This is how socio-ecological inequality and urbanization drive each other in Bogotá.

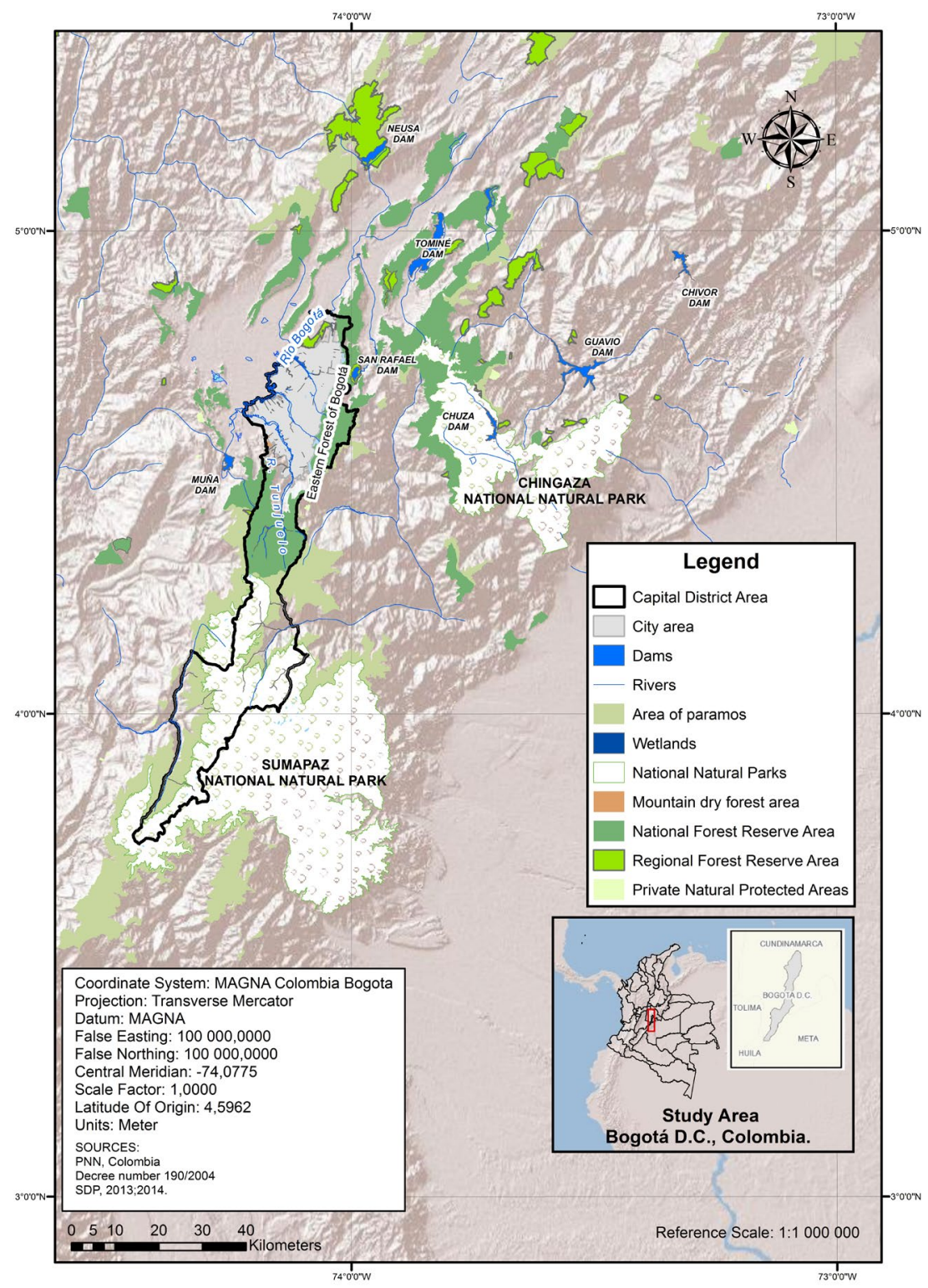

Figure 1: Sabana de Bogotá high plateau and some elements of the MES. Source: the author.

\footnotetext{
${ }^{6}$ Bogotá-region is a land of water. Ecological transformation of pre-existing wetland areas it had reduced them from 50,000 hectares in 1938 to only 500 in 2005 (Gallini 2014 et al.). This had direct implications of biodiversity loss, for instance, of endemic bird species (Calvachi 2003).

${ }^{7}$ These conflicts are reported in the Environmental Justice Atlas: https://ejatlas.org/
} 


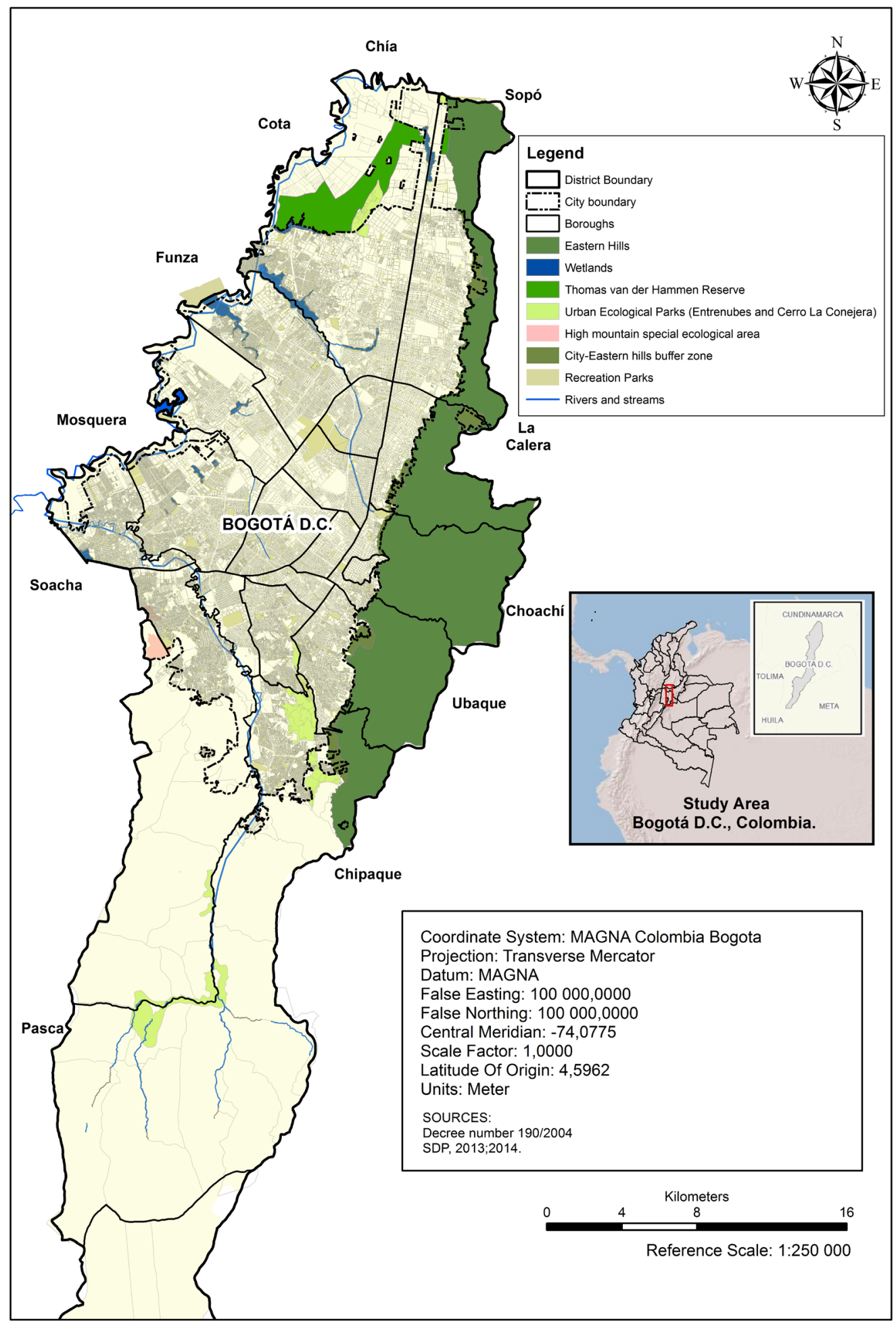

Figure 2. City of Bogotá and some elements of the MES. Map: the author. 


\section{Methodology and research sources}

The research conducted in Bogotá covers a time frame from the late 1980s to the present. My research approach considers Bogotá as a case study of multiple environmental motivations, conflicts, and stakeholders driving urban nature advocacy at the metropolitan scale. My research is mainly based on the review and content analysis of governmental and policy documents, reports, scholarly literature, and some documents produced by social and civic organizations. Most of the material was collected during my previous professional experience in Bogotá working as a practitioner and consultant in several policy-making and research roles among different institutions, including ongoing engagement with local key organizations. Additional documentation was collected during two field trips (April 2017 and November 2017-January 2018), during which I also conducted unstructured interviews with two social leaders and three practitioners, and one group interview with five members of a local NGO. ${ }^{8}$ I also traced the social mobilization of environmental issues using the Social Struggle Data Base produced by the Center for Research and Popular Education in Colombia (CINEP). The research materials also include participatory observations and field notes.

\section{Findings: people, urban planning, and nature}

\section{From housing struggles to a city-region environmental movement}

Since the late 1980s a set of social movement organizations in Bogotá has been promoting urban nature advocacy, emerging as an environmental movement (movimiento ambientalista). They have been building a territorial attachment with some elements of urban nature through the re-appropriation of regulations, and technical-scientific concepts, such as the MES. As noted in the introduction, the term used for this sort of attachment is "environmental territories" (territorios ambientales) (Julio and Hernández 2014). Upon the reappropriation of the MES concept, people involved in urban nature advocacy have managed to achieve a level of consensus and identity and have boosted a participatory process, using their situated knowledge to intervene in urban planning debates. Table 1 summarizes the environmental concerns related to the main stakeholders in Bogotá. ${ }^{9}$

This process of political mobilization around environmental issues has been a way to contest unequal urbanization that destroys the urban commons through urban development in protected areas and the unequal allocation of high impact activities, such as quarrying or landfills. But, how did this environmentalization of social mobilization take place?

It is noteworthy that although a number of settlements and communities overlapped with, or were located near, ecosystems now framed under the MES, most of their claims about the right to the city between the late 1970s and late 1980s were not presented in terms of rights to 'nature.' However, with hindsight, those claims would have been totally pertinent in an environmental struggle. For instance the housing supply failed to keep up with the burgeoning demand generated by increasing urban growth and densification. The housing shortage was both quantitative and qualitative, and became a serious problem for urban planning policy (Hataya 1996). The mode of acquisition of sites for housing was mainly through illegal occupations or acquired through informal contracts from so-called "pirate developers" (urbanizadores pirata). Likewise, the quality of housing suffered due to inadequate construction and unavailability of basic urban infrastructure services like water, sewerage, and electricity. Although legal regulations existed, the state was overwhelmed with increasing urbanization and the growth of informal settlements. The most critical issue was the powerful real estate agencies exercising influence over local authorities, and private interests indulging in land speculation (Jaramillo 1992). As a result, regulations became increasingly ambiguous, favoring these interests. This situation was a driving force for many urban struggles (Naranjo Botero 2014).

\footnotetext{
${ }^{8}$ Due to reasons of confidentiality the names of people interviewed are not given.

${ }^{9}$ Certainly there have been more organizations involved which are not listed due to the research scope. In addition, some NGOs such as Corporación ECOFONDO, The Center for Research and Popular Education-CINEP, Medio Ambiente y Desarrollo-ENDA América Latina, and Fundación para la Investigación, Educación y desarrollo para el Hábitat PopularFIDHAP, have actively supported several grassroots mobilizations.
} 


\begin{tabular}{|l|l|}
\hline \multicolumn{1}{|c|}{ Environmental concern or value } & \multicolumn{1}{c|}{$\begin{array}{c}\text { Main social movement organizations and NGO } \\
\text { involved }\end{array}$} \\
\hline Eastern Hills (Cerros Orientales) Defense & $\begin{array}{l}\text { Mesa de Cerros Orientales, Amigos de la Montaña, } \\
\text { Fundación Cerros de Bogotá, Veeduría Ciudadana por } \\
\text { los Cerros Orientales. }\end{array}$ \\
\hline Bogotá River Defense & Somos Río Bogotá, Fundación al Verde Vivo. \\
\hline Urban Wetlands Defense & $\begin{array}{l}\text { Red de Humedales (Late 1990s - Early 2000s), Fundación } \\
\text { Humedales Bogotá, Fundación Humedal La Conejera, }\end{array}$ \\
& $\begin{array}{l}\text { Fundación Humedal Torca-Guaymaral, Fundación } \\
\text { Asinus, Fundación Grupo de Semillas, Fundación Adessa } .\end{array}$ \\
\hline The Tunjuelo River Watershed & $\begin{array}{l}\text { Proceso Asamblea Sur, Mesa de Concertación Interlocal } \\
\text { Usme-Ciudad Bolivar, Territorio Sur, Parque Entrenubes. }\end{array}$ \\
\hline The Fucha river & Corporación Vida del Río Fucha CORVIF. \\
\hline The Salitre river & Amigos del Salitre-AMISALITRE. \\
\hline Farming and Peasant Organizations & $\begin{array}{l}\text { Mesa de Concertación Local de Usme, Sindicato Agrario, } \\
\text { Fensuagro, Sintrapaz, Corpoagrofusunga, PROCAMSU, } \\
\text { ASOSUMAPAZ Horizonte Verde. }\end{array}$ \\
\hline $\begin{array}{l}\text { Regional Forest Reserve of North Bogotá (Since } \\
\text { 2011: the Urban Forest Reserve Thomas van der } \\
\text { Hammen) }\end{array}$ & $\begin{array}{l}\text { Veeduriu Ciudadana por la Reserva Thomas van der } \\
\text { Hammen, Sembradores de la Reserva Thomas van der } \\
\text { Hammen. }\end{array}$ \\
\hline Cerro Seco Defense, at south Bogotá. & $\begin{array}{l}\text { Mesa Ambiental de Ciudad Bolivar, Colectivo "No le } \\
\text { Saque la Piedra a la Montaña. }\end{array}$ \\
\hline
\end{tabular}

Table 1: Environmental concerns related to main stakeholders in Bogotá. Source: Julio and Hernandez 2014; EAAB-CI 2003; SDP, SDH, and Patrimonio Natural 2015; and unpublished sources.

In the second half of the 1980s, the Colombian government, in alliance with the United Nations Development Agency, promoted projects for state decentralization functions in urban planning such as "Integrated Actions in Popular Urban Settlements" in Bogotá. The aim was to propose administrative mechanisms of action that would make it possible to overcome alarming levels of underdevelopment of housing in boroughs ${ }^{10}$ such as Ciudad Bolivar, Santa Fe, San Cristóbal and Suba. This opened a space for mainstreaming urgent needs of communities, and led to the formulation of Local Emergency Plans (PEZ) ${ }^{11}$, a participatory exercise which allowed communities to organize their needs through local workshops. But the PEZ was not a state initiative; rather, it was a materialization of an idea promoted at the National Communal Congress held in the city of Pasto, in 1985. The original intention was to confront state programs which claimed to apply "participatory planning", because local communities saw those programs as a means of political cooptation. Through the PEZ they actually were seeking to negotiate with government agencies without any other mediation. This experience became a blueprint in participatory urban planning in Bogotá (Corte and González Posso 1989).

Beside needs such as water supply and sewerage, public transport, education and human security, in the case of Ciudad Bolivar the PEZ included a claim about making improvements in "recreation, arts, and ecology." According to practitioners interviewed who worked with social organizations in the 1980s, environmental issues were already in discussion by then. Indeed, environmental awareness had also entered discussions outside academic circles. For instance, the First National Congress of Ecologists "Econgente", held in the city of Pereira, in 1983, was a blueprint for the formal establishment of the "Colombian environmental movement"

\footnotetext{
${ }^{10}$ Before 1992 such areas were known as zonas.

${ }^{11}$ Except for MES or POT, since here I favored the use of the acronyms used in Spanish.
} 
(see Tobasura Acuña 2007). ${ }^{12}$ However, environmental issues only got on the governmental agendas in the following decade (Uribe 1998). Meanwhile, Bogotá was suffering deteriorating urban environmental conditions, such as lack of green areas, landfills in the middle of suburbs (Gibraltar and El Cortijo), and a worrying situation with the dramatic pollution of the Bogotá River which flooded the poorest settlements. At the end of the twentieth century, researchers including biologists and ecologists began to turn their gaze to their own neighborhoods in the city, away from the tropical forests beaten up by the armed conflict (c.f. Ruiz 2008); likewise, intellectuals and elites were promoting environmental awareness through new ways in the public sphere. Moreover, three international and national milestones boosted environmental discourse at the local level and, above all, reaffirmed the claims for social justice: first, the publication of Our common future (WCED 1987) had an enormous impact on local scholars and NGOs; second, ecological principles were established at the National Constitution of 1991 and; third, the Earth Summit was held in Rio de Janeiro in 1992. As one interviewee said:

From daily life and need, the environment [discourse] enriched the effort to pursue a dignified life. In that sense, that is why many people and groups saw in the city [referring to urban ecosystems] ... fragments of the city, fragile, spaces to recover (...). (Practitioner 1. Emphasis by the author).

After the enactment of a new National Constitution in 1991, the release of Law 1421 in 1993 established the Organic Statute (Estatuto Orgánico) re-organizing Bogotá's political-administrative structure and tax regime (República de Colombia 1993a). This allowed authorities to legalize dozens of neighborhoods, expand basic urban services, and improve public space. At this point, it is important to mention two prominent civic action structures in Bogotá: the Communal Action Boards (JAC) and the Local Management Boards (JAL). JAC were institutionalized in the late 1950s and were defined almost as the only channel of communication between communities and state entities, but becoming the locus of patronage (Gutiérrez 1998). Later, after the release of the Law 1421, the JAL were established at the level of boroughs with the premise of decentralizing power and promoting participatory democracy. However, the result was quite the opposite. Although most of basic urban services were resolved by state intervention, in the last few decades both the JAC and JAL have lost their influence in mobilizing people and promoting participation in local politics, because of co-optation by particular political interests. This meant that social movements in Bogotá were no longer exclusively organized by specific neighborhoods or under traditional democratic institutions alone, as they used to be.

In some of the most segregated boroughs, such as Ciudad Bolivar and San Cristóbal, most social movement organizations have been engaged in contentious collective actions to create new spaces for political participation as a means to contest both state policies of repression over marginalized and stigmatized communities, and the eruption of paramilitarism, drug-trafficking and crime in their neighborhoods (Peña 2014; Zibechi 2008). Such contentious collective actions were reflected in the emergence of myriad resources and structures all driven by communities, youth groups, urban dwellers, and farmers of Bogotá's rural areas, networks in daily life ${ }^{13}$ (i.e. friends, families, neighborhoods), networks of organizations, and local workshops (Julio and Hernández 2014; Torres Carrillo 2002). Organized groups started to work under various common cultural, religious, and environmental interests. Moreover, technical and financial support coming from different sources, not only from state agencies but also from NGOs or international cooperation, was an important driver force behind political mobilization.

After the Rio Summit in 1992, and the enactment of a new National Constitution in 1991, Colombia strengthened the implementation of environmental institutions and regulations. Among these were the endorsement of the Convention on Biological Diversity, the Ramsar Convention, some commitments about natural risks and disasters (c.f. Brand and Thomas 2005), and the enactment of Law 99 in 1993 (República de

\footnotetext{
12 This movement has been moving constantly back and forth from conservationism, environmental management, and ecoefficiency to environmental justice and popular environmentalism; likewise, it has embraced scholars, intellectuals, practitioners, and grassroots members in rural and urban areas.

13 The leadership of women in these networks has been fundamental.
} 
Colombia 1993b), which set up an institutional arrangement called the National Environmental System (SINA). This allowed the creation of the Ministry of the Environment as a lead authority to guide the rules for different levels of administration and action due to state decentralization. For instance, environmental authorities were established for the main cities and metropolitan areas. In Bogotá, the Municipal Environmental Office (first a Technical Department: (DAMA), later a Municipal Office (Secretaria de Ambiente) was established as the environmental authority in the urban area of Bogotá, whereas the authority in rural areas was a regional autonomous office, CAR-Cundinamarca.

In terms of participatory environmental democracy, legal tools and other mechanisms were also established. For instance, between 1993-1994 there was an exercise engaging several stakeholders in proposing "Environmental Local Planning" agendas (Agendas Locales Ambientales) for each borough. These agendas promoted participatory and concrete environmental programs and actions, as a part of a big program of environmental education and participation called "Viva Bogotá Viva" commissioned by the Municipal Administration. However, the existence of this institutional setting did not ensure an improvement of environmental management and policy (Quimbayo-Ruiz 2016). Social movements and activists have complained about institutionalized means of participation, because those means have become a formality manipulated by certain political interests (Londoño 2008). Nonetheless, people and organizations have had to mobilize using the available mechanisms established by the National Constitution of 1991, including the right to making popular claims (Law 472) (República de Colombia 1998).

In the debates over environmental concerns, land-use and urban planning, including watershed management have been crucial topics (i.e. for the Bogotá River), and in this regard, the concept of MES has taken an important place. Existing legal regulations are rather ambiguous, because ecosystem considerations in land-use regulations have been treated as an obstacle for land development (c.f. Rubiano Galvis and Esteban García 2016). In Bogotá urban planning debates have formed one of the most important arenas of action for social movements regarding these matters. Foremost, the formulation of the POT (District Decree 619-2000) based on the National Law 388 of 1997, and a later update (District Decree 190-2004) were approved without having any reform ever since and with no regard to other proposals, and this became a highly debated topic (Ardila 2003; Confluencia Social y Académica 2009; Alcaldía Mayor de Bogotá 2013). In addition, the District Agreement 12 of 1994 established a consultancy body for urban planning - the District Territorial Planning Council, or CTPD - the members of which are representatives from civil society (Concejo de Bogota 1994).

Public debates around the POT embraced grassroots movements, practitioners, and scholars in the context of several hearings and citizens meetings convened either by the Municipality through its offices or by the environmental movement organizations. Elements of the MES such as hills, wetlands, rivers and streams, have been the main components in these urban planning debates, and social movement organizations have pushed authorities to take into consideration the value of urban nature, mobilizing environmental concerns at the city-region level. In so doing, situated knowledge from people at the territorios ambientales has interacted with scientific and technical expertise in urban ecology and law, coming from engaged practitioners and scholars.

In fact, environmental mobilization around protection of elements of the MES, such as rivers and their watersheds, has been remarkable. The case of the Tunjuelo watershed, in south Bogotá, deserves special attention. The Tunjuelo is the largest of four watersheds in the District with a total human population approaching two million (around $25 \%$ of city's total population). The socio-ecological imbalances of the urbanrural continuum that characterize the District's southern area are clear in this watershed (Osorio 2007). Such imbalances are due to socio-spatial segregation, insufficient urban planning, and disastrous flooding in the middle and lower river basin (Sánchez 2012). There is also high-impact activities such as quarrying for the building sector (Fierro 2013), or the municipal landfill "Doña Juana". Because of such imbalances, important grassroots mobilizations have emerged in the watershed, including associations of farming communities from the rural-urban fringe (Gómez et al. 2016), and local protected areas, such as Entrenubes park, have been established (Quimbayo Ruiz 2012).

Wetlands are other important elements of the MES, with biodiversity values persisting despite the negative effects of urbanization (Calvachi 2003). Springing from neighborhoods close to wetlands, 
environmental movements have been very active since the 1990s in the conservation of these spaces against urban development. They mobilized politically through social and legal advocacy, later being supported by other concerned stakeholders such as biologists and lawyers (c.f. Remolina 2015). Although wetlands were recognized by local authorities in the mid-1990s, it was not until 2004 via the POT, and later in 2006 under the formulation of a specific public policy (Decree 624 2007), that they became legally protected as a result of social mobilization. This policy-making process has been considered one of the most important achievements of local environmental advocacy, mainly by the emergence of a network of social mobilizations - Red de Humedales - (Palacio et al. 2003) whose two focal points were La Conejera and Córdoba wetlands, in Suba, northwest Bogotá. In 2018, 11 of these urban wetlands were designated by the Colombian state as RAMSAR wetlands.

Finally, one of the most long-lived environmental struggles has developed around the ambiguous status that the National Protected Forest Reserve of the Cerros Orientales has had since its creation in 1976. The protection measures of the Reserve became embroiled in legal disputes (Rojas-Pinilla 2017), as well as conflicts involving people from neighborhoods dating from before the establishment of the Reserve, some which faced eviction in the name of disaster risk reduction (Allen et al. 2015). Much of this housing was built by illegal developers, but some of these communities have since established Ecobarrios as a means to claim their right to live in the hills area in a more sustainable way (Ome 2017). In 2013 a National Court recognized the reality of the area and committed to reconciling conservation with social problems among stakeholders. However, the struggle for the Cerros continues to create tensions between local and regional authorities, real estate developers and the local inhabitants. In 2016, a Citizen's Observatory (Veeduria) was established to maintain social accountability.

In sum, the stakeholders involved in urban nature advocacy in Bogotá include a wide array of social groups from diverse socio-economic conditions and backgrounds (see Table 1 above). They engage in a variety of means of actions (see Table 2) where everyday practices and knowledge informs urban planning initiatives aimed at protecting nature. The organizations reflect the complex geographies of the city-region, as they are from both urban and rural areas (around $75 \%$ of total land of the municipality) in Bogotá, and involve farmers, peasant organizations, and recognized indigenous groups such as the Muisca people.

\section{Advocacy of nature institutionalized}

The pathway taken by Bogotá's environmental movement has been marked by its relationship to the state. During Mayor Enrique Peñalosa's first administration (1998-2000), heated debates took place between environmental movement organizations and state authorities around urban planning and the protection of areas with ecological interest such as wetlands (Serrano 2010). With backing from other levels of government (i.e. regional and national), the protection of such ecological areas through political mobilization and legal advocacy was achieved (see Table 2). This stopped, at least momentarily, development intentions coming from Peñalosa's administration. Since the 2000s, an important number of activists from environmental mobilizations have held positions in public offices in recognition of their advocacy work. This also might be a result of local elections which brought political parties into the Municipal Government that favor social concerns. ${ }^{14}$ In addition, some grassroots organizations established affiliations with these parties, gaining political influence. As a result, social activists and organizations were not only lobbying the City Council of Bogotá but also reaching positions there as councillors (concejales), or as civic dignitaries (ediles). Other representatives of grassroots organizations became staff or obtained leading administrative roles in government institutions. During the period 2004-2015, official documents concerning participatory action on environmental concerns reported steps towards enhancing actions and policies between institutions and communities (Figure 3).

\footnotetext{
${ }^{14}$ Two of the three administrations in that term, Mayor Luis E. Garzón, and Mayor Samuel Moreno. Their mandate heading into local elections was under a left coalition Polo Democrático Alternativo-PDA. Moreno's administration was involved in a big corruption scheme to carry out urban infrastructure projects. The Carrusel de la Contratación involved politicians from across the political spectrum, and private contractors. Moreno was sentenced in 2016 to 18 years in prison for his direct involvement in the case. Gustavo Petro, who used to be a member of PDA, won the elections in 2011 with his own political party Progresistas, and after denouncing the corruption scheme.
} 


\begin{tabular}{|c|c|}
\hline Goals and actions & Instruments, tools, activities \\
\hline Participation to reach informed consent & Petitions of right (Derecho de petición), newsletters, etc. \\
\hline $\begin{array}{l}\text { Participation in urban planning and } \\
\text { environmental policies, and regulation debates }\end{array}$ & $\begin{array}{l}\text { Popular legal advocacy initiative } \\
\text { Public Hearings } \\
\text { Participation in discussions about specific urban } \\
\text { planning and environmental policies instruments (i.e. } \\
\text { POT, City Administration Plans, district policies) }\end{array}$ \\
\hline Political participation & $\begin{array}{l}\text { Popular consultancy } \\
\text { Citizen oversight and accountability } \\
\text { Open councils }\end{array}$ \\
\hline $\begin{array}{l}\text { Participation in administrative decision-making } \\
\text { processes }\end{array}$ & $\begin{array}{l}\text { Consultancy boards } \\
\text { Prior consultancy actions } \\
\text { Environmental administration intervention } \\
\text { Participation in environmental authorities board of } \\
\text { directors meetings }\end{array}$ \\
\hline Participation in justice administration & $\begin{array}{l}\text { Action of Trusteeship (Acción de tutela) } \\
\text { Popular claim (Acción popular) } \\
\text { Compliance action (Acción de cumplimiento) } \\
\text { Penalty actions }\end{array}$ \\
\hline Other activities & $\begin{array}{l}\text { Eco-villages (Ecobarrios) } \\
\text { Communitarian ecological restoration } \\
\text { Education and awareness-building } \\
\text { Urban gardening and farming } \\
\text { Walks and rallies in urban ecosystems } \\
\text { Fair trade, eco-business, among others, eco-tourism } \\
\text { and/or environmental consultancy }\end{array}$ \\
\hline
\end{tabular}

Table 2: Means of action of environmental organizations in Bogotá. Original source: Julio and Hernandez 2014. Modified by the author.

A similar level of engagement was also seen in the Municipal Water Company (Empresa de Acueducto), in the management of the city's water system, including wetlands, rivers, and streams. The explicit support of environmental issues during Mayor Gustavo Petro's administration (2012-2015) is noteworthy. As Zeiderman (2016a) has described, Petro and his staff found in the issue of climate change a valid vehicle to promote progressive urban politics and social justice. This allowed the administration to redesign governance institutions around risk management and climate change mitigation, engaging communities and organizations in the implementation of a range of adaptation initiatives, such as watershed management plans, early warning systems, and participatory budgeting workshops. The proposal to revise the POT to include ecosystem and climate change criteria was the most remembered of such initiatives. However, Petro's administration faced strong opposition:

...[from those] who saw Bogotá's future through the lens of capital investment, and his [Petro's] revised master plan [the POT] was a lightning rod for criticism. (Zeiderman 2016a: 390) 

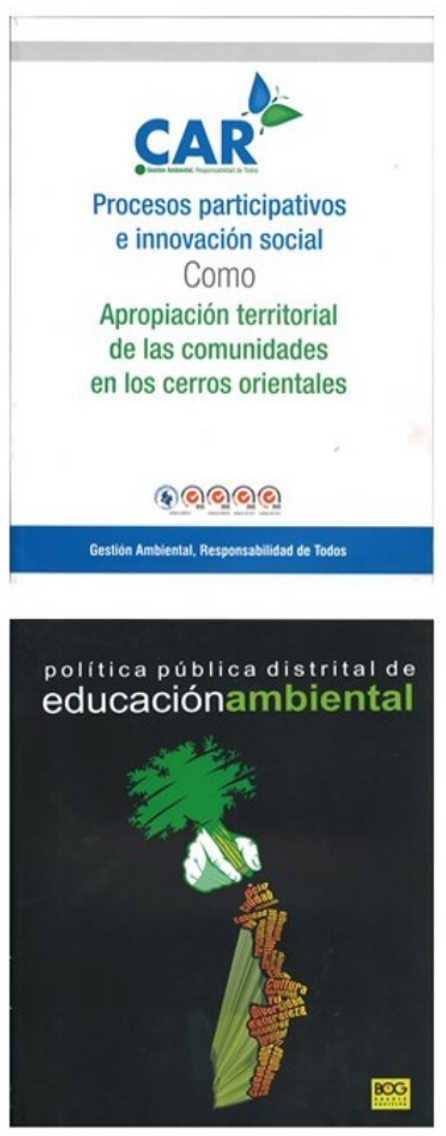
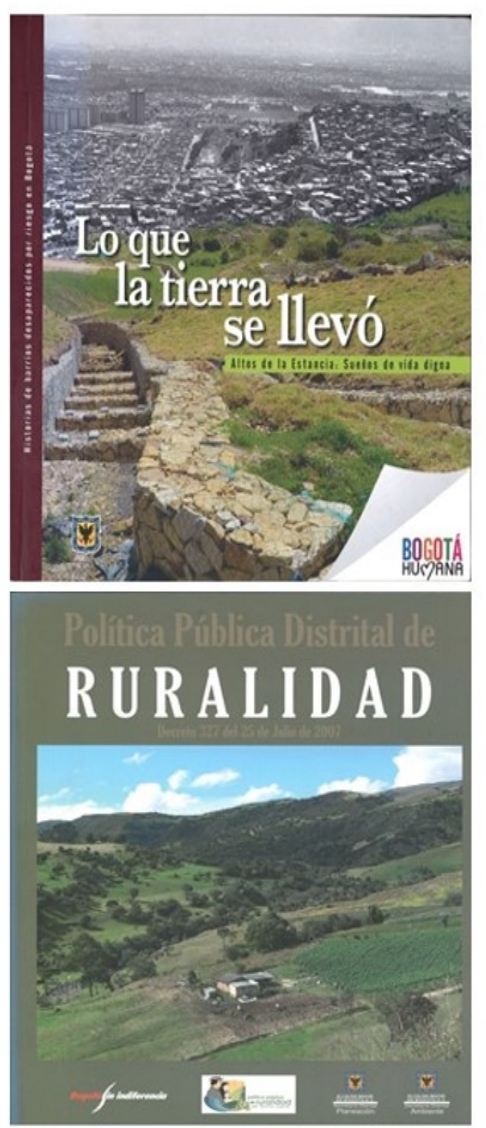
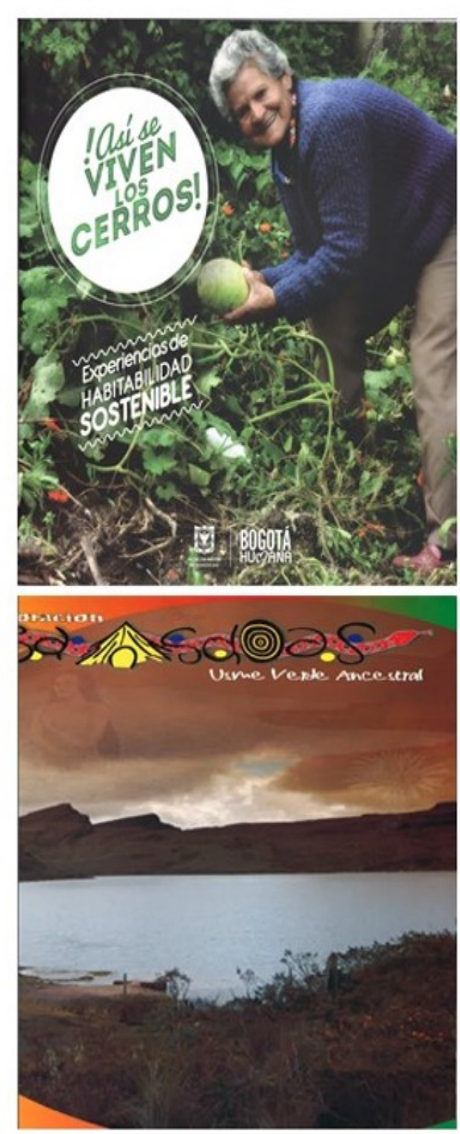

Figure 3: Documents reporting joint work between government institutions and civic organizations. Scans: the author.

Despite advances across urban planning policies relating to urban nature, there are still conflicts around protected areas management, including failed interventions and administrative discontinuities, and recent retreats in public policy for wetland protection. For instance, the current administration of Mayor Enrique Peñalosa (his second term: 2016-2019), has announced large-scale urban development projects overlapping with important elements of the MES; among others, the Urban Forest Reserve Thomas van der Hammen (henceforth: TvdH). This reserve in northern Bogotá seeks to consolidate 1,395 hectares for public uses such as ecological restoration, education, and recreation. Interests coming from the real-state sector, with respective lobbying in state agencies, have completely blocked the full materialization of such a project, because they are instead interested in developing the area (see Ardila 2003; Rubiano Galvis and Esteban García 2016). The opposition to development by social organizations has been ignored, in spite of the previous administration having been active in consolidating the Reserve. Social organizations have been spreading technical and legal information through social media platforms, such as Twitter and Facebook, amongst many others, as a way to offer key elements for the public debate, and to counteract official acts coming from the municipal administration. This has helped, for example, to reinforce legal advocacy against state institutions made by citizen oversight groups who defend the TvdH reserve. The situation with the TvdH reserve resonates with that of many other climate change policies mobilized by the environmental movement, while Peñalosa's administration is drafting a new POT for the next 12 years disregarding several environmental issues. 
The successive administrations and mayors of Bogotá from the 1990s to the present day, regardless of political affiliation, have distinguished themselves (although with different approaches) by promoting urban transformations in a context of economic globalization, and the influence of national and transnational capital flows, including large investments in marginalized areas. This urban political process has been embedded in a volatile political landscape (see Gilbert 2015) marked by corruption and the lack of a long-term shared vision enduring from one mayor and administration to another. The City Council has also been criticized by civil society, because representatives usually favor particular interests and are erratic in their promotion of progressive policies. Political processes in Bogotá are characterized by a technocratic emphasis, especially in the late 1990s and early 2000s, better in terms of social justice in the 2012-2015 period. Thus urban and environmental policies in recent years form a heterogeneous assemblage and an unstable combination of ideas and techniques of local governance, and would not have been possible without the everyday agency of people (c.f. Pérez Fernández 2010; Pérez 2016; Suárez 2017; Zeiderman 2016a).

\section{Contradictions in everyday practices}

Common concerns emerged in interviews conducted with participants in the environmental movement. It seems that the participatory spaces promoted by government institutions were designed with the premise of guaranteeing diversity in participation, but without full success:

(...) the thing is that there are a lot of complaints, raised by the same people who took part, regarding how these policies have not been implemented as they should have been. [For instance], let's say there is a policy which on paper is very good, and it has many positive things, but in practice they have not been able to implement it (...). (Local leader 1).

Likewise, some social leaders and activists noted disengagement among the people involved, who only get together for specific events such as a demonstration, or a tree-planting working bee. There is a common complaint among them that participatory mechanisms and institutionalization have actually helped to fragment social mobilization.

Listen, there are no such environmental movement organizations anymore, they are persons. When we met La Conejera, there were leaders; Petro [former mayor] arrived and they vanished. And they were only one person, not an organization. For example, one of the leaders says to represent an organization, but is only that person. (Local leader 2)

It also seems that contradictions in the ethos of being an activist (ambientalista) and the lack of persistence of the movement are conditioned by material or financial resource shortcomings in everyday life:

(...) This is an issue that we have pointed out many times, which is basically that to be an activist does not feed us [laughs], then there is a lot of resignation. (...) We have to fall into the institutions or do another job to survive...It's the same feeling, even for those who usually criticize the very institutions but end up working for them. (Local leader 1. Emphasis by the author).

This could explain why other social leaders and activists decided to adopt a more entrepreneurial approach, creating NGOs to do consultancies or offering services such as ecotourism, environmental education, and bird watching (Table 1). Moreover, some participants pointed out in a group interview that there were individual cases of people who were accused of benefitting personally from doing politics with government agencies, and thus "betraying" the activist movement. Another feature expressed was the kind of experience lived by some individuals when they worked in governmental offices or agencies. No matter if they were a social worker or a 
head officer, even with enough political will at the forefront of decision-making, people faced tough bureaucratic mechanisms frequently restricting or distorting the application of policies (c.f. Pérez 2016).

On the other hand, there seems to have been little social impact in terms of mobilization of the environmental movement in Bogotá, according to the Social Struggle Data Base produced by CINEP. Out of 2,451 events observed between 1990 and 2014 in Colombia, only 43 (1.75\%) (and 29 in Bogotá, 1.18\%) corresponded to actions (i.e. mobilizations, protests, demonstrations or strikes) claimed by civil society and explicitly related with environmental motivations such as pollution and impact on natural resources. In fact, only seven $(0.28 \%)$ of those actions were events promoted by social movement organizations certainly recognized as environmental activists. Other motivations claimed by social movement organizations in Bogotá that could be related with environmental issues as well, such as housing, water supply, sewerage, waste management, impacts of megaprojects, land use conflicts, natural risks and disasters, and human and labour rights, raise the number to $61(2.48 \%)$.

These numbers began to increase in recent years. During the National Agrarian Strike (Paro Nacional Agrario) in 2013, for instance, it was worth noting the importance of cities like Bogotá in welcoming a significant number of demonstrations against the recent opening of extractive agricultural or mining-energy activities across the country (CINEP 2014). But environmental conflicts in Bogotá region were not reported as much, although at the national level environmental conflicts have recently increased (Pérez-Rincón 2015; Pérez-Rincón et al. 2018). Finally, the records from CINEP corroborate claims by interviewees about the peaceful character of the movement, because most of these events were marches and mobilizations. Nevertheless, some individuals and organizations suffered verbal and physical violence, even with fatal consequences. Even though in Bogotá violence rates have decreased noticeably in the recent years, historically, Colombia is still one of the most dangerous places to be a social activist, and, even more so for those involved in environmental conflicts. ${ }^{15}$

Stepping back from the CINEP records, during the last year (2017-2018) environmental conflicts concerning urban nature in Bogotá have raised political tensions. Peñalosa's administration and several groups of citizens are struggling over not only the TvdH reserve, but other issues related to unequal urbanization and the urban commons in Bogotá-region as well. For instance, there is a movement called "No le saque la piedra a la montaña" ("Don't enrage the mountain") against illegal quarrying activities for building materials in the southern hills in Ciudad Bolivar. Young activists are insisting on the right to live in a worthy landscape, in a marginalized area, through the promotion of a protected area called Cerro Seco. However, this social movement organization has not received the same visibility as its counterpart on the north of the city $(\mathrm{TvdH})$, which has more resources, and allies among certain intellectuals. Even so, to gain visibility people in Ciudad Bolivar have begun to refer to Cerro Seco as "la van der Hammen del sur" ("the van der Hammen reserve of the south").

\section{Concluding remarks}

Environmental awareness in Bogotá has its most important roots among the working class and grassroots, backstopped by intellectuals, experts, and practitioners. Struggles around basic urban services are environmental struggles. Colombian social movements reflect a complex process of pursuing the democratization of social and political mobilization (Archila 2006; Velasco 2014), and the idea of a "longstanding" democratic system and the rule of law have been called into question by systemic corruption by the State, a long armed political conflict, and the persistence of paramilitarism, drug-trafficking, and crime. Such a setting has constrained democratization, as the CINEP's database records suggest. However, the main role of Bogotá's environmental movement has been to keep alive environmental concerns within local urban planning agendas and debates.

People and organizations from social movements have mobilized concepts such as the MES to show how administrative or political boundaries are effectively useless in addressing concrete socio-ecological inequalities. Situated knowledge exists in the struggle to address socio-ecological inequalities throughout urban-rural continuums and it is included in efforts to establish urban commons, regardless of specific political-

\footnotetext{
${ }^{15}$ Recently, Global Witness has been tracking this horrific trend: https://goo.gl/keudKf (Last accessed 31 January 2018).
} 
administrative divisions. But, paradoxically, social movements have also contested the scattered and weak implementation of regulatory measures by using available legal tools provided by the institutionalization of environmental concerns in law. More recently, the use of social media has also facilitated the formalization of legal and institutional arrangements. This is how situated knowledge intertwines with normative and technicalscientific concepts, strengthening social struggles. Power is not only legitimated by hegemonic expert knowledge represented by state institutions and legislation. Rather, the legitimacy of knowledge and law is cocreated by communities confronting the institutions that represent state power.

Situated knowledge practices are among the main driving forces in negotiating change in most political struggles (Tilly 1999), something that is very important to take into account in ongoing environmental struggles in Latin America. Socio-economic circumstances, inequalities, and power relations are shaping social movement organizations action at the everyday level. This article shows that there is a myriad of social movement organizations with different interests nuanced by class, gender, or privileged positions. More research is needed to understand how situated knowledge intertwines with normative and technical-scientific concepts to shape the everyday dynamics of each one of the environmental conflicts mentioned in this article. Also, while the focus here is on urban nature, many related environmental conflicts in Bogotá must be also examined (i.e. air pollution, waste management).

Austin Zeiderman's work in Bogotá (2016a, b) has already shown how environmental issues such as climate change imperatives can offer lessons for current urban debates. This article has shown how situated sustainable narratives are embodied in mechanisms such as the MES which, at the same time, promote debates over who has the right to the city. Bogotá, like other urban areas, experiences increasing climate change vulnerability (IDEAM 2017), and environmental concerns are today under daily scrutiny in the public sphere, especially among younger advocates. As Bulkeley et al. $(2013,2014)$ argue, it is necessary to keep in mind that urban climate change issues must be addressed differently in particular geographies, with the aim of avoiding misleading conceptual generalizations or totalizing narratives (i.e. "green cities"). Social movements in Bogotá have had the opportunity to be participants but not always decision-makers, in the construction of public policies, whereas urban planning is still dominated by experts (Beuf 2016) and crucial decisions are still taken by the few (Gallini 2016). Nevertheless, among such organizations there lies a process of social innovation for urban nature advocacy through individual and collective actions - political mobilization that addresses the question of for whom urban space should be. Maintaining the struggle to protect urban nature is still a legitimate vehicle to overcome urban injustices.

\section{References}

Agrawal, A. 2005. Environmentality: technologies of government and the making of subjects. Durham: Duke University Press.

Allen, A., R. Lambert, A. Apsan and T. Ome. 2015. Can participatory mapping activate spatial political practices? Mapping popular resistance and dwelling practices in Bogotá eastern hills. Area 47(3): 261271.

Allen, A., A. Lampis and M. Swilling (eds.). 2016. Untamed urbanisms. London: Routledge.

Ándrade, G. I., F. Remolina and D. Wiesner. 2013. Assembling the pieces: a framework for the integration of multi-functional ecological main structure in the emerging urban region of Bogotá, Colombia. Urban Ecosystems 16(4): 723-739.

Arboleda, M. 2016a. Spaces of extraction, metropolitan explosions: planetary urbanization and the commodity boom in Latin America. International Journal of Urban and Regional Research 40(1): 97-112.

Arboleda, M. 2016b. In the nature of the non-city: expanded infrastructural networks and the political ecology of planetary urbanisation. Antipode 48(2): 233-251.

Ardila, G. (ed.). 2003. Territorio y sociedad: el caso del POT de la ciudad de Bogotá. Bogotá, Colombia: Universidad Nacional de Colombia. Ministerio del Medio Ambiente de Colombia.

Armiero, M. and L. Sedrez (Eds.). 2014. A history of environmentalism. Local struggles, global histories. London. New York: Bloomsbury. 
Archila, M. 2006. Los movimientos sociales y las paradojas de la democracia en Colombia. Revista Controversia 186: 9-32.

Auyero, J. and D.A. Swistun. 2009. Flammable. Environmental suffering in an Argentine shanty town. New York: Oxford University Press.

Beuf, A. 2016. Las centralidades urbanas como espacios concebidos: referentes técnicos e ideológicos de los modelos territoriales del Plan de Ordenamiento Territorial (POT) de Bogotá, Colombia. Cuadernos de Geografia: Revista Colombiana de Geografia 25(2): 199-219.

Brand, P. and M. Thomas. 2005. Urban environmentalism: global change and the mediation of local conflict. London: Routledge.

Bulkeley, H., J. Carmin, V. Castán Broto and G. Edwards. 2013. Climate justice and global cities: mapping the emerging discourses. Global Environmental Change 23(5): 914-925.

Bulkeley, H., G. Edwards and S. Fuller. 2014. Contesting climate justice in the city: examining politics and practice in urban climate change experiments. Global Environmental Change 25: 31-40.

Burchardt, H. J. and K. Dietz. 2014. (Neo-) extractivism - a new challenge for development theory from Latin America. Third World Quarterly 35(3): 468-486.

Buttel, F. 1992. Environmentalization: origins, processes and implications for rural social change. Rural Sociology 57(1): 1-27.

Calvachi, B. 2003. Una aproximación al conocimiento actual de los humedales, lagunas y embalses de Bogotá y la Sabana. In Acueducto de Bogotá y Conservación Internacional Colombia (eds.). Los humedales de Bogotá y la Sabana, Volumen 1. Bogotá, Colombia: Acueducto de Bogotá y Conservación Internacional.

Carrizosa, J. 2014. Colombia compleja. Bogotá, D.C., Colombia: Jardín Botánico de Bogotá José Celestino Mutis. Instituto de Investigación de Recursos Biológicos Alexander von Humboldt.

Centro de Investigación y Educación Popular-CINEP. 2014. Luchas sociales en Colombia. Informe especial del Programa por la Paz. Bogotá, Colombia: CINEP.

Confluencia Social y Académica. 2009. ¿Quién ordena a quién, y qué se ordena en el territorio? A propósito de la revisión del POT de Bogotá. Bogotá, Colombia: CINEP-Intermón Oxfam-Agencia Catalana de Cooperación.

Corte, B. and C. González Posso. 1989. Planeación urbana y participación popular en Bogotá. Bogotá: Centro de Investigación y Educación Popular-CINEP.

Davidson, M. and K. Iveson. 2015. Recovering the politics of the city: From the 'post-political city'to a 'method of equality'for critical urban geography. Progress in Human Geography 39(5): 543-559.

Delgado, G.C. 2015. Water and the political ecology of urban metabolism: the case of Mexico City. Journal of Political Ecology 22: 98-114.

Departamento Nacional de Planeación-DNP-. 2015. Bogotá. Fichas e indicadores territoriales. Document online. [Last accessed: 31 January 2018].

Di Chiro, G. 2008. Living environmentalisms: coalition politics, social reproduction, and environmental justice. Environmental Politics 17(2): 276-298.

Di Chiro, G. 2016. Environmental justice and the Anthropocene meme. In T. Gabrielson, C. Hall, J, Mayer and D. Schlosberg (eds.) The Oxford handbook of environmental political theory. United Kingdom: University of Oxford Press.

Dikeç, M. and E. Swyngedouw. 2017. Theorizing the politicizing city. International Journal of Urban and Regional Research 41(1): 1-18.

Díaz, C. 2011. Metabolismo de la ciudad de Bogotá D.C.: una herramienta para el análisis de la sostenibilidad ambiental urbana. Masters thesis, Magister en Medio Ambiente y Desarrollo. Bogotá, Colombia: Universidad Nacional de Colombia. Facultad de Ciencias Económicas. Instituto de Estudios Ambientales-IDEA. 
Echeverría, M.C. and A. Rincón. 2000. Ciudad de territorialidades: polémicas de Medellín [City of territorialities: polemics from Medellín]. Medellín: Centro de Estudios del Hábitat Popular and Universidad Nacional de Colombia.

Empresa de Acueducto y Alcantarillado de Bogotá-EAAB y Conservación Internacional Colombia-CI. 2003. Los humedales de Bogotá y La Sabana. Bogotá: EAAB y CI.

Erensü, S. and O. Karaman. 2017. The work of a few trees: Gezi, politics and space. International Journal of Urban and Regional Research 41(1): 19-36

Ernstson, H. 2013. The social production of ecosystem services: a framework for studying environmental justice and ecological complexity in urbanized landscapes. Landscape and Urban Planning 109(1): 7-17.

Ernstson, H. and S. Sörin. 2013. Ecosystem services as technology of globalization: on articulating values in urban nature. Ecological Economics 86: 274-284.

Erixon Aalto, H. and H. Ernstson. 2017. Of plants, high lines and horses: civic groups and designers in the relational articulation of values of urban nature. Landscape and Urban Planning 157: 309-321.

Fernández Álvarez, A. 2012. Neoliberalism and parks: the urban political ecology of green public space in Mexico City. Sociedad Hoy 23: 83-115.

Fierro, J. 2013. Una aproximación sintética sobre los impactos ambientales de la minería no legal. In L.J. Garay (Ed.). Minería en Colombia: institucionalidad y territorio, paradojas y conflictos. Vol. 2. Bogotá: Contraloría General de la República.

Gallini, S. 2016. The zero garbage affair in Bogotá. In C. Mauch (ed.) A future without waste? Zero waste in theory and practice. RCC Perspectives: Transformations in Environment and Society. Munich: Rachel Carson Center for Environment and Society.

Gallini, S. and C. Castro. 2015. Modernity and the silencing of nature in Nineteenth-century maps of Bogotá. Journal of Latin American Geography 14(3): 91-125

Gallini, S., L. Felacio, A. Agredo and S. Garcés. 2014. The city's currents: a history of water in 20th-century Bogotá. Environment and Society Portal. Document online. [Last accessed: September 24 2018]

Gilbert, A. 2015. Urban governance in the South: how did Bogotá lose its shine? Urban Studies 52(4): 665684.

Gómez, G., F. Montenegro, G. Quimbayo and C. Matallana. 2016. Otra forma de ser ciudad: biodiversidad y comunidades campesinas en el borde sur de Bogota. In Mejía M. (ed.). Naturaleza urbana. Bogotá D.C., Colombia: Instituto de Investigación de Recursos Biologicos Alexander von Humboldt.

Gudynas, E. 2009. Diez tesis urgentes sobre el nuevo extractivismo: contextos y demandas bajo el progresismo sudamericano actual. In J. Schuldt, A. Acosta, A. Barandiará, A. Bebbington, M. Folchi, CEDLA, A. Alayza and E. Gudynas (eds.). Extractivismo, política y sociedad. Quito, Ecuador: CAAP/CLAES.

Gutiérrez, F. 1998. La ciudad representada. Política y conflicto en Bogotá. Bogotá, Colombia: Universidad Nacional de Colombia-Instituto de Estudios Políticos y Relaciones Internacionales -IEPRI- and Tercer Mundo Editores.

Haase D., S. Kabisch, A. Haase, E. Andersson, E. Banzha, F. Baró, M. Brenck, L.K. Fischer, N. Frantzeskaki, N. Kabisch, K. Krellenberg, P. Kremer, J. Kronenberg, N. Larondelle, J. Mathey, S. Pauleit, I. Ring, D. Rink, N. Schwarz, M. Wolff. 2017. Greening cities - to be socially inclusive? About the alleged paradox of society and ecology in cities. Habitat International 64: 41-48.

Haesbaert, R. 2013. Del mito de la desterritorialización a la multiterritorialidad. Cultura y representaciones sociales 8(15): 9-42.

Hataya, N. 1996. Expanding urban sprawl: growth of low income settlements in Bogotá, Colombia. The Developing Economies 34(4): 497-519.

Harvey, D. 2012. Rebel cities: from the right to the city to the urban revolution. London: Verso.

Horowitz, L. 2015. Local environmental knowledge. In T. Perreault, G. Bridge and J. McCarthy (eds.). The Routledge handbook of political ecology. New York: Routledge. 
Instituto de Hidrología, Meteorología and Estudios Ambientales-IDEAM. 2017. Análisis de vulnerabilidad y riesgo por cambio climático para los municipios de Colombia. Bogotá: IDEAM, PNUD, MADS, DNP, CANCILLERÍA.

Jaramillo, S. 1992. La vivienda en Bogotá: evolución de las condiciones habitacionales y de la estructura de producción de vivienda. Bogotá: Documento CEDE No 87, Universidad de los Andes.

Julio, M. Á. and A. Hernández (eds.). 2014. Territorios ambientales de Bogotá. Historias de acción colectiva. Bogotá: Secretaría Distrital de Ambiente. Centro Interdisciplinario de Estudios sobre el Desarrollo de la Universidad de Los Andes.

Lawhon, M., H. Ernstson and J. Silver. 2014. Provincializing urban political ecology. Antipode 46 (2): $497-$ 516.

Li, F. 2015 Unearthing conflict: corporate mining, activism, and expertise in Peru. Durham: Duke University Press.

Londoño, B. 2008. Las organizaciones no gubernamentales ambientales colombianas y su ejercicio de las herramientas de participación institucionalizada. In Rodríguez B.M. (ed.). Gobernabilidad, instituciones $y$ medio ambiente en Colombia. Bogotá: Foro Nacional Ambiental.

Loftus, A. 2012. Everyday environmentalism: creating an urban political ecology. Minneapolis, USA: University of Minnesota Press.

Martínez-Alier, J., I. Anguelovski, P. Bond, D. Del Bene, F. Demaria, J.F. Gerber, L. Grey, W. Haas, H. Healy, V. Marín-Burgos, G. Ojo, M. Porto, L. Rijnhout, B. Rodríguez-Labajos, J. Spangenber, L. Temper, R. Warlenius and I. Yánez. 2014. Between activism and science: grassroots concepts for sustainability coined by environmental justice organizations. Journal of Political Ecology 21: 19-60.

Martínez-Alier, J., H. Sejenovich and M. Baud. 2015. El ambientalismo y ecologismo latinoamericano. In F. de Castro, B. Hogenboom and M. Baud (eds.). Gobernanza ambiental en América Latina. Buenos Aires, Argentina: Consejo Latinoamericano de Ciencias Sociales-CLACSO.

Massey, D. 1992. Politics and space/time. New Left Review 196: 65-84.

Merrifield, A. 2013. The urban question under planetary urbanization. International Journal of Urban and Regional Research 37(3): 909-922.

Naranjo Botero, M. 2014. Provivienda: protagonista de la colonización popular en Colombia. Historia y Memoria 9: 89-118.

Ome, T. 2017. An ethnography of Bogotá's ecobarrios: understanding the construction process of place-based eco-political subjects, subjectivities and identities through an institutional programme and a local resistance strategy. Doctoral thesis. London: The Bartlett Development Planning Unit. University College of London (UCL).

O'Neill, K. 2012. The comparative study of environmental movements. In P. Steinberg and S. VanDeveer (eds.). Comparative environmental politics. theory, practice, and prospects. Cambridge: The MIT Press.

Osorio, J. 2007. El río Tunjuelo en la historia de Bogotá, 1900-1990. Bogotá: Alcaldía Mayor de Bogotá. Secretaría Distrital de Cultura, Recreación y Deporte.

Oxfam. 2016. "Privilegios que niegan derechos." Desigualdad extrema y secuestro de la democracia en América Latina y el Caribe. Reino Unido: Iguales-Oxfam Internacional.

Palacio, D., R. Hurtado and L. Garavito. 2003. Redes en tensión. el caso de la gestión ambiental de los humedales de Bogotá. Redes revista hispana de análisis de redes sociales 4(6): 1-31.

Parra, A. and L. Gitahy. 2017. Movimiento social como actor - red: ensamblando el comité por la defensa del agua y del páramo de Santurbán. Universitas Humanistica 84(84): 113-139.

Pauchard, A. and O. Barbosa. 2013. Regional assessment of Latin America: rapid urban development and social economic inequity threaten biodiversity hotspots. In T. Elmqvist, M. Fragkias, J. Goodness, B. Güneralp, P. J. Marcotullio, R. I. McDonald and C. Wilkinson (eds.). Urbanization, biodiversity and ecosystem services: challenges and opportunities. New York: Springer. 
Peña, L.B. 2014. Acciones colectivas contenciosas, proceso político y seguridad urbana. Construyendo geografías de la esperanza. Territorios 31: 57-83.

Pérez, F. 2016. Excavating legal landscapes: juridical archaeology and the politics of bureaucratic materiality in Bogotá, Colombia. Cultural Anthropology 31(2): 215-243.

Pérez Fernández, F. 2010. Laboratorios de reconstrucción urbana: hacia una antropología de la política urbana en Colombia. Antípoda 10: 51-84.

Pérez-Rincón, M.A. 2015. Conflictos ambientales en Colombia: actividades generadoras, impactos y mecanismos de resistencia. Ecología Política 48: 76-82.

Pérez-Rincón, M., J. Vargas-Morales and Z. Crespo-Marín. 2018. Trends in social metabolism and environmental conflicts in four Andean countries from 1970 to 2013. Sustainability Science 13(13): 635648.

Pintos, P. 2017. Extractivismo inmobiliario y vulneración de bienes comunes en la cuenca baja del río Luján. In A. Vásquez Duplat ed.). Extractivismo urbano: debates para una construcción colectiva de las ciudades. Buenos Aires, Argentina: Fundación Rosa Luxemburgo, Centro de Estudios y Acción por la Igualdad. El Colectivo.

Programa de las Naciones Unidas para el Desarrollo-PNUD. 2011. Colombia rural. Razones para la esperanza. Informe Nacional de Desarrollo Humano. Bogotá: INDH PNUD.

Quimbayo Ruiz, G.A. 2012. Parque Entrenubes: ciudad, conservación y movimientos sociales en el sur de Bogotá. Revista Historia Ambiental Latinoamericana y Caribeña (Halac) 2(1): 24-46.

Quimbayo Ruiz, G.A. and F. Vásquez Rodríguez. 2016. Hacia una ecología política de la urbanización en Latinoamérica. Ecologia Política 51: 43-51.

Quimbayo-Ruiz, G.A. 2016. Gestión integral de la biodiversidad en el Distrito Capital: aportes para una gobernanza urbana. Biodiversidad en la Práctica. Documentos de Trabajo del Instituto Alexander von Humboldt 1(1): 44-76.

Remolina, F. 2015. Role of local stakeholders in reaching, developing, and sustaining collaborative management: case study of urban wetlands of Bogotá, Colombia. Masters thesis, Social-ecological resilience for sustainable development programme, Faculty of Science. Stockholm: Stockholm University.

Rojas-Pinilla, H. 2017. Cronología de las prácticas de ordenamiento, conflicto e intratabilidad: el caso de la reserva del Bosque Oriental de Bogotá. Territorios 36: 111-137.

Rubiano Galvis, S. and V. Esteban García. 2016. Las corporaciones autónomas regionales (CAR) y la regulación ambiental del territorio a propósito de la disputa por el borde norte de Bogotá. In H. Alviar Garcia and E. Lamprea (coord). El Estado regulador en Colombia. Bogotá: Universidad de los Andes.

Ruiz, M. 2008. Lineamientos para una historia agro-ambiental de la Sabana de Bogotá (1850-1999). In G. Palacio (ed.). Historia ambiental de Bogotá y la Sabana, 1850-2005. Leticia, Colombia: Instituto Amazónico de Investigaciones, Universidad Nacional de Colombia.

Sánchez, V. 2012. Segregación socio-espacial y cambio ambiental en Bogotá, siglo XX: el caso del río Tunjuelo. XII Coloquio de Geocritica. Conference Paper online [Last accessed: 8 August 2017]. http://www.ub.edu/geocrit/coloquio2012/actas/07-F-Sanchez.pdf.

Santos, M. 2000. El territorio: un agregado de espacios banales [The territory: an assembly of banal spaces]. Boletin de Estudios Geográficos 96: 87-96.

Scheidel, A., L. Temper, F. Demaria and J. Martínez-Alier. 2018. Ecological distribution conflicts as forces for sustainability: an overview and conceptual framework. Sustainability Science 13(3): 585-598.

Schlosberg, D. 2007. Defining environmental justice: theories, movements and nature. Oxford: Oxford University Press.

Schwarz, A. and M. Streule. 2016. A transposition of territory: decolonized perspectives in current urban research. International Journal of Urban and Regional Research 40(5): 1000-1016. 
Secretaría Distrital de Planeación-SDP. 2014. Región metropolitana de Bogotá: una visión de la ocupación del suelo. Colección integración regional No. 11. Colombia: Alcaldía Mayor de Bogotá-SDP.

Secretaría Distrital de Planeación-SDP-, Secretaría Distrital del Hábitat-SDH- y Patrimonio Natural. 2015. ¡Así se viven los Cerros! Experiencias de habitabilidad. Colombia: Alcaldía Mayor de Bogotá y Patrimonio Natural.

Secretaría Distrital de Planeación-SDP. 2017. Administración Peñalosa le apunta a nuevo modelo de desarrollo rural sostenible. Document online. [Last accessed: June 27, 2018]

Sedrez, L. 2013. Urban nature in Latin America: diverse cities and shared narratives. In C. Leal, J. Padua and J. Soluri (eds.). New environmental histories of Latin America and the Caribbean. RCC Perspectives. Munich: Rachel Carson Center for Environment and Society.

Serrano, N. 2010. Renovación urbana y conservación ambiental: el caso del humedal de Córdoba en Bogotá. In M.C. Serje (ed.). Desarrollo y conflicto. Territorios, recursos y paisajes en la historia oculta de proyectos y politicas. Bogotá: Universidad de los Andes.

Shillington, L. 2011. Urban political ecology in the Global South: everyday environmental struggles in Managua, Nicaragua. In T. Edensor and M. Jayne (eds.) Urban theory beyond 'the West': a world of cities. London: Routledge.

Suárez, A. 2017. Bogotá en el limbo. Estructuras de poder que se lucran de la capital. Bogotá: Debate.

Svampa, M. 2012. Consenso de los commodities, giro ecoterritorial y pensamiento crítico en América Latina. Observatorio Social de América Latina-OSAL. Consejo Latinoamericano de Ciencias SocialesCLACSO 13(32): 15-38.

Swyngedouw, E. 1996. The city as a hybrid: on nature, society and cyborg urbanization. Capitalism, Nature, Socialism 7(2): 65-80.

Thibert, J. and G. A. Osorio. 2014. Urban segregation and metropolitics in Latin America: the Case of Bogotá, Colombia. International Journal of Urban and Regional Research 38(4): 1319-1343.

Tilly, C. 1999. Survey article: power-top down and bottom up. The Journal of Political Philosophy 7(3): 330352.

Tobasura Acuña, I. 2007. Ambientalismos y ambientalistas: una expresión del ambientalismo en Colombia. Ambiente \& Sociedade 10(2): 45-60.

Torres Carrillo, A. 2002. Organizaciones populares, construcción de identidad y acción política. Revista Latinoamericana de Ciencias Sociales, Niñez y Juventud 4(2): 1-22.

Ulloa, A. 2015. Environment and development: reflections from Latin America. In T. Perreault, G. Bridge and J. McCarthy (eds.). The Routledge handbook of political ecology. New York: Routledge.

Uribe, E. 1998. La gestión ambiental en Bogotá -1995-1997. In E. Ponce de León, F. A. Galán y E. Uribe. Gestión ambiental nacional y urbana. Bogotá, Colombia: Foro Nacional Ambiental.

Van der Hammen, T. 1998. Plan ambiental de la cuenca alta del río Bogotá. Análisis y orientaciones para el ordenamiento territorial. Santa Fé de Bogotá, Colombia: Corporación Autónoma Regional de Cundinamarca-CAR.

Velasco, M. 2014. Social movement contention in Colombia, 1958-2014. In P. Almeida, A. Cordero Ulate (eds.). Handbook of social movements across Latin America. Netherlands: Springer Science.

World Commission on Environment and Development, WCED. 1987. Our common future. Oxford: Oxford University Press.

Wolford, W. and S. Keene. 2015. Social movements. In T. Perreault, G. Bridge and J. McCarthy (eds.). The Routledge handbook of political ecology. New York: Routledge.

Zeiderman, A. 2016a. Adaptative publics: building climate constituencies in Bogotá. Public Culture 28(2): 389413.

Zeiderman, A. 2016b. Endangered city: the politics of security and risk in Bogotá. Durham: Duke University Press. 
Zibechi, R. 2008. América Latina: periferias urbanas, territorios de resistencia. Bogotá: Ediciones Desde Abajo.

\section{Policy and legal documents}

Alcaldía Mayor de Bogotá. 2004. Plan de Ordenamiento Territorial de Bogotá. Departamento Administrativo de Planeación Distrital. Document online [Last accessed: September 24 2018].

Alcaldía Mayor de Bogotá. 2007. Adopción de la política de humedales del Distrito Capital. Document online [Last accessed: September 24 2018].

Alcaldía Mayor de Bogotá. 2013. Las grandes polémicas sobre la modificación excepcional del POT [MEPOT]. Bogotá: Secretaría Distrital de Planeación, Secretaría Distrital de Ambiente. Document online [Last accessed: September 24 2018].

Concejo de Bogotá. 1994. Estatuto de planeación del Distrito Capital y se reglamenta la formulación, la aprobación, la ejecución y la evaluación del plan de desarrollo económico y social y de obras públicas del Distrito Capital de Santa Fe de Bogotá. Bogotá. Document online [Last accessed: September 24 2018].

República de Colombia. 1993a. Decreto Número 1421. Por el cual se dicta el régimen especial para el Distrito Capital de Santa Fé de Bogotá. Bogotá: Presidencia de la República. Document online [Last accessed: September 24 2018].

República de Colombia. 1993b. Ley 99. Ley general ambiental de Colombia. Bogotá: Congreso de la República. Bogotá. Document online [Last accessed: September 24 2018].

República de Colombia. 1997. Ley 388. Por la cual se modifica la ley $9^{a}$ de 1989, y la ley $3^{a}$ de 1991. Bogotá: Congreso de la República. Bogotá. Document online [Last accessed: September 24 2018].

República de Colombia. 1998. Ley 142. Acciones populares y de grupo en Colombia. Bogotá: Congreso de la República. Bogotá. Document online [Last accessed: September 24 2018]. 